\title{
A CAPSULE HISTORY OF ANAESTHESIA IN CANADA*
}

\author{
R.A. GORDON
}

The purpose of this lecture is to present a brief review of the development of the specialty of anaesthesia in Canada, from its beginnings to the present. As I proceed I will endeavour to reflect the influence of changes in society and the profession of medicine on the development of anaesthesia. I will say something of the pioneers of the specialty in Canada and their significant contributions, and look briefly at the present state of the guild.

\section{Early History}

At the time of Morton's demonstration of ether anaesthesia in Boston, Canada as we know it today did not exist. Instead there were, across the northern part of this continent, a series of British Colonies, each with a government independent of the others, dependent in varying degree on the Government of Great Britain, and communicating and trading more freely with the United Kingdom and the United States than with one another. On the Atlantic coast the colonies of Newfoundland, Nova Scotia, New Brunswick and Prince Edward Island; to the west the politically united colony of Canada, divided by origin and culture and geographically into Upper Canada or Canada West (now part of Ontario) and Lower Canada or Canada East (now Quebec).

The mass of land from Lake Superior and Hudson's Bay to the Pacific Ocean and north to the Arctic belonged by grant to the Hudson's Bay Company and was inhabited in 1846 by a few fur traders dispersed amongst the indigenous Indian tribes. Most of it was still unexplored wilderness. Excluding the indigenous peoples, the total population of these colonies in 1848 numbered scarcely two million. There were no great cities and most of the inhabitants were busily engaged in clearing forests to create farm lands or were

*The Lewis Wright Memorial Lecture, presented at the Annual Meeting, American Society of Anesthe siologists, New Orleans, La., October 18, 1977.

R.A. Gordon, C.D., M.D., F.R.C.P.(C), F.F.A.R. C.S., Hon.F.F.A.R.C.S. Professor Emeritus, Dept. of Anaesthesia, University of Toronto, $178 \mathrm{St}$. George Street, Toronto, Ontario, M5R 2M7.

Canad. Anaesth. Soc. J., vol. 25, no. 2, March 1978 engaged in the fur trade. Industry was local and craft-oriented.

The medical profession of the colonies was derived originally from adventurous spirits who arrived as ships' surgeons. These remained chiefly in the Maritime Provinces and Lower Canada. The profession in Upper Canada was drawn principally from British army surgeons who were stationed there after it became a province in 1791, and especially during the war of $1812-14$, and who remained in the colony after retiring from the service. Some of these possessed high professional competence. By the year 1815 the province of Upper Canada had a total of only 36 physicians and surgeons.

The first medical schools in Canada were opened in 1843. In that year L'Ecole de Medicin et Chirurgie was established at Quebec, and Dr. John Rolph opened a medical school at Toronto. By 1846 there were three medical journals published in Canada; these were the Quebec Medical Journal, inaugurated in 1826, the British American Journal of Medical and Physical Science, and the Montreal Medical Gazette, both published in Montreal from 1845. Otherwise the profession relied principally on British periodicals.

This then, was the state of Canadian society, the profession and the public means of professional communication when the demonstrations of Wells and Morton gave surgical anaesthesia to the world.

\section{First Uses of Anaesthesia in Canada}

Several claims have been made for the first use of anaesthesia in Canada. Attempts to establish historical priorities can be frustrating and even dangerous if regional sensibilities are involved. This has been long evident in medicine, and the sad story of the Morton and Long controversy should be adequate evidence of this for any anaesthetist. It would seem to be not important, really, who gave the first anaesthetic in Canada. However, considering the state of travel and communication at the time, it is surprising how quickly the news of anaesthesia spread, and how soon it was practised in Canada. 
Ether was used by Dr. James Douglas of Quebec City during amputation of the toes some time before February 20, 1847. ${ }^{1}$ Dr. Horace Nelson of Montreal reported that, following experiments with ether on animals, his friends and himself, he had, on February 20, 1847, removed a tumour from the thigh of a woman under the influence of ether administered by Mr. Webster, a dentist. ${ }^{2}$ Dr. Edward Worthington of Sherbrooke claimed to have performed the "first capital operation in Canada under the influence of ether on 14 March, $1847^{\prime}$. 3

Ether anaesthesia was used in Halifax, Nova Scotia, soon after the Morton demonstration in Boston, the ether being administered by Lawrence Van Buskirk, a dentist, for an amputation done by Dr. Daniel McNeill Parker. The date is uncertain, but in his memoirs ${ }^{4}$ Dr. Parker says "Lawrence Van Buskirk, a dentist, practising in Halifax at the time, as soon as he learned that ether was being used by inhalation there in practical dentistry, with commendable enterprise visited Boston and familiarized himself with its use".

It is interesting that the early use of ether in Upper Canada (now Ontario) is not documented in the medical literature of the day. Dr. David Steward has recently discovered that such references do exist in the lay press of the period, ${ }^{5}$ and it would seem that the mystery of the rapid dissemination of the ether story is solved by the wide publication in the lay press of Dr. John C. Warren's report in the Boston Medical and Surgical Journal. This was one of the news stories of the day. Figure 1 is an example of such a report from The Globe in Toronto on December 23, 1846. The same report was printed in a number of other newspapers in the region about the same time.

Asicle from the few original reports from Nova Scotia and Lower Canada, which I have cited, there is surprisingly little evidence in the Medical Press of the use of ether in practice. We find some evidence, however, in the lay press, as. in the advertisement in the St. Lawrence Republican of Ogdensburgh, New York, of May 3, 1847, shown in Figure 2. Dr. Ambler was a surgeon practising in Brockville, Upper Canada, and Dr. Blodgett practised dentistry in both Ogdensburgh and Brockville. These two towns face one another across the St. Lawrence River. During the same period the partners were advertising regularly in The Brockville Recorder. By the end of $1848 \mathrm{Dr}$. Blodgett was offering chloroform instead of "Letheon". 5

Chloroform largely replaced ether for the pro-

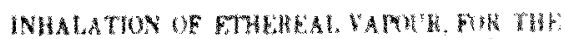

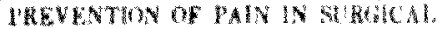
OTERAM

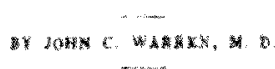

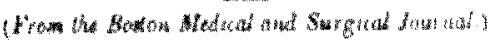

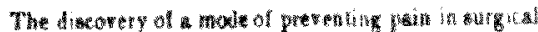

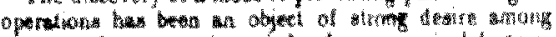

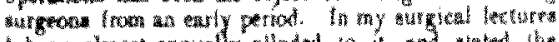

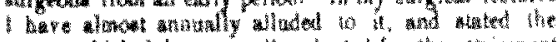

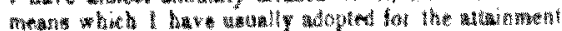

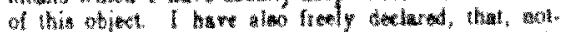

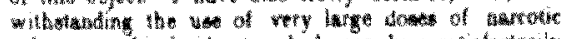

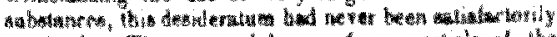

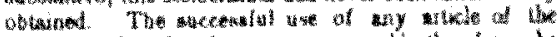

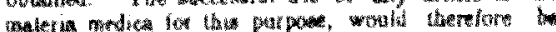

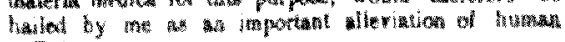
sederite.

Figure 1 Report of the use of ether in Boston in October, 1846; from The Globe, Toronto, December 23, 1846. (From the Archives of Ontario. Reproduced with kind permission of The Globe and Mail.) Reproduced from STEWARD, D.J. The early history of anaesthesia in Canada: the introduction of ether to Upper Canada, 1847. Can. Anaes. Soc. J. 24: 153-161 (1977).

duction of anaesthesia in Canada after its introduction. It will be recalled that Sir James Young Simpson first employed chloroform in Edinburgh on November $4,1847.6$ It is interesting that the same Dr. Daniel Parker of Halifax, who has been mentioned in conncction with the introduction of ether into Nova Scotia, had been Sir James Simpson's clinical clerk prior to 1845 . Chloroform was used for anaesthesia in Halifax on February 5,1848 , for amputation of a finger by $D r$. Almon, in the presence of Dr. Parker. ${ }^{4}$ The chloroform was produced by J.D.B. Fraser, Chemist, of Pictou, Nova Scotia, who had the method for preparing chloroform "from a British

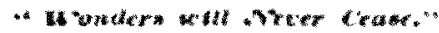

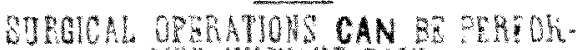 N. 3 WITOUY PAIN.}

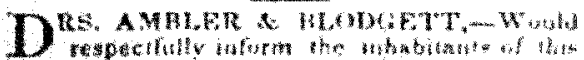

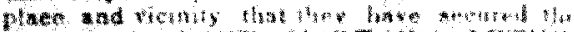

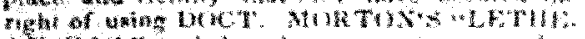

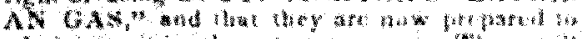

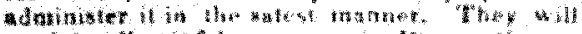

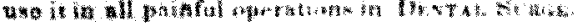

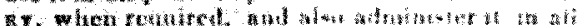

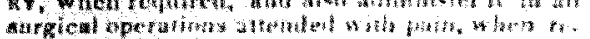

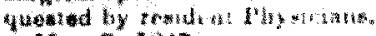

May 1717

Figure 2 Advertisement that appeared in the $S t$. Lawrence Republican, Ogdensburgh, New York, May 3, 1847. (From the Archives of the Ogdensburg Public Library, with kind permission.) Reproduced from STEWARD, D.J. The early history of anaesthesia in Canada: the introduction of ether to Upper Canada, 1847. Can. Anaes. Soc. J. 24: 153-161 (1977). 
Publication". This has been celebrated as the first use of chloroform in Canada, but it is a matter of record that the drug was employed earlier by Dr. Worthington for surgery in Sherbrooke, Lower Canada, on January $24,1848,7$ that it was first used in midwifery by Dr. A.F. Holmes of Montreal on January $25,{ }^{8}$ and that Dr. James Sewell administered the first chloroform anaesthetic at the Hotel Dieu de Quebec on February 3 . $1848 .^{9}$

The fact that all these "first" uses of chloroform occurred within a period of 12 days in separate localities indicates a common source of information delivered to each of the innovators at approximately the same time. Undoubtedly this source was Simpson's paper entitled "Discovery of a New Anaesthetic Agent more Efficient than Sulphuric Ether", in the London Medical Gazette of November 10, 1847. The same issue of the British American Journal of Medical and Physical Science which contains Holmes' report also has a reprinting of Simpson's communication, including a method for producing chloroform.

The preference for chloroform over ether as an anaesthetic agent was undoubtedly due to its greater potency and portability, in an era when a large proportion of surgery and almost all obstetrics was domiciliary. The rural practitioner making his rounds on horseback and his colleague in town with his horse and buggy could easily carry chloroform and a towel with him. Ether was more bulky and cumbersome and slower in its action. This ascendency of chloroform in anacsthetic practise continued into the first decade of this century, when concern for the mortality and morbidity associated with this agent and the development of the early anaesthetic machines stimulated a return to nitrous oxide and ether in urban hospital practise. In rural practise and in obstetrics, however, the use of chloroform was still common up to the beginning of World War II.

The history of anaesthesia in Canada has differed from that in the United States in the sense that, following the British tradition, the administration of an anaesthetic has always been considered to be the prerogative of the physician or the dental surgeon, and from the earliest times the role of the dentist in anaesthesia has been confined to its application in dental surgery.

Originally and for many decades the physician anaesthetist did not have any special training in this art. When an operation was contemplated the anaesthetic was given by whatever physician was available and willing. Usually he had little know- ledge of his patient. To quote Dr. Samuel Johnson: 10 "Like all other branches of the art of healing, anaesthesia in the beginning was very crude. It would have been just as crude as medicine or surgery, but for the lack of opportunity. Death by anaesthesia was not quite so painful or harrowing to the patient as slow death under the torture of the miscellaneous weapons of the surgeons or the bleedings and leeches of the enthusiastic physicians. At this time almost anyone who could hold a mask and pour on some drug was allowed to administer an anaesthetic. Some of the physicians and surgeons, however, realized the seriousness and importance of anaesthesia and gave considerable attention to the subject."

There are few or no records available of the anae sthetic practise in our major hos pitals during the first half-century after Morton, but an occasional vignette provides a glimpse of the state of the art. A report from the lay press of a coroner's inquest into the first death from chloroform in the Toronto General Hospital, in 1863, provides us with the information that fewer than 2,000 chloroform anaesthetics had been given in the hospital to that time, ${ }^{11,12}$ but there is no information available about those anaesthetics. This was the second death from chloroform recorded in Canada, the first being at Montreal General Hospital in August, $1861 .{ }^{13} \mathrm{It}$ is also evident that not all patients and surgeons were persuaded of the benefits of anaesthesia. One of our hospital historians has recorded that, in the Toronto General Hospital, the last patient was operated on without anaesthesia in 1868. That patient was an old sailor who had previously had a leg amputated without anaesthesia and who refused an anaesthetic for amputation of his tongue for "pipe cancer". ${ }^{14}$

During the last decade of the nineteenth century the medical superintendent of the Toronto General Hospital had a special interest in anaesthesia and instructed and supervised the house surgeons, who were the usual anaesthetists for the hospital patients. One of those house surgeons, in recording his experience in 1890 and 1891, wrote as follows: "Now and again a patient would take chloroform badly, and sometimes would stop breathing. On such occasions, if it were during the winter, Dr. O'Reilly would rush out and look for a large icicle. This would be inserted into the rectum and in some instances it was remarkable to see how quickly the patient responded to the stimulus." "1s (Charles Roland16 points out that this is not one of Canada's contributions to the art of resuscitation since the 
Lancet of August 2, 1873 noted that a Dr. Baillee, writing in an Italian journal, recommended the insertion of ice in the rectum for "chloroform intoxication'.)

The same Dr. Charles O'Reilly published an anaesthetic chart for use in hospital practise which is, as far as I can determine, the first such form to be published (Figure 3). This appeared in Canadian Lancet for August, 1901. ${ }^{17}$ (The only copy of this publication available to me had the relevant page cut out, and this copy is a reproduction published by Charles Roland in 1968. ${ }^{16}$ ) This antedates by two years Cushing's influential paper $^{18}$ on determining blood pressure in the operating room. l am sure you will be interested in the list of instruments and materials required: and here, again, ice for the rectum! Note that amongst "restoratives", whiskey is ranked well above oxygen gas!

The history proper of anaesthesia as a medical specialty in Canada begins in the first years of this century. It is recorded that in $1899 \mathrm{Dr}$. Hutton

AN ANAESTHETIC CHART.

The following chart arranged by Dr. Charles O Reilly. of the Toronto General Hospital. has been widely adopied in Hospital practice.

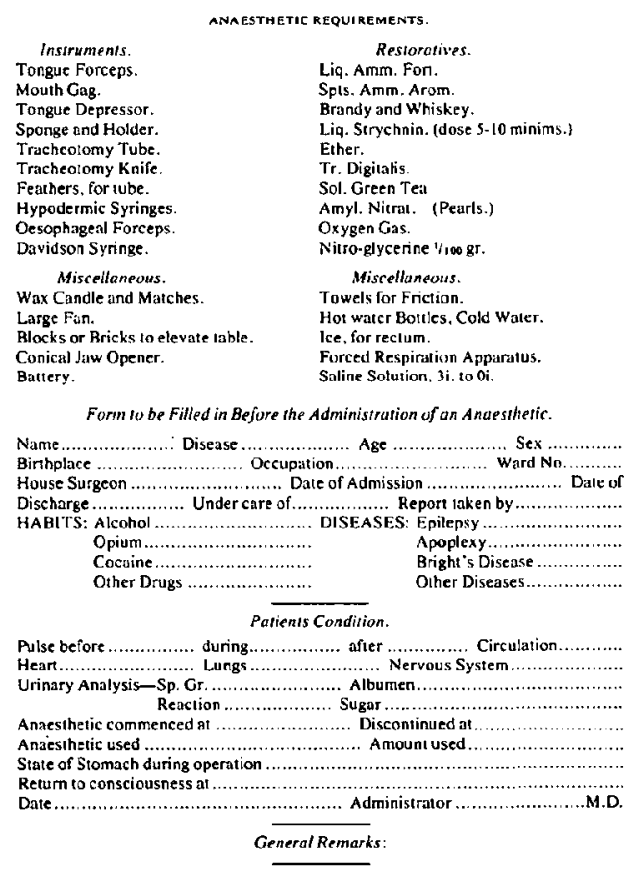

FIGURE 3 Anaesthetic chart published by $\mathrm{Dr}$. Charles O'Reilly. Canadian Lancet 34: 636 (1901). Reproduced from RoLAND, C.G. Bibliography of the history of anaesthesia in Canada: preliminary check list. Can. Anaes. Soc. J. 15:202-214 (1968). was appointed honorary anaesthetist to the Winnipeg General Hospital. He was succeeded in 1901 by Dr. Chestnut and in 1902 Dr. William Webster was appointed to the post. ${ }^{19}$ Webster had spent some time in Britain in 1897 and had been influenced by the work of Hewitt, Buxton and others, who were devoting their full time to anaesthesia as a specialty. He was particularly impressed by the laboratory research into anaesthesia going forward at that time in Britain. In 1905 he was appointed Lecturer in Anaesthesia at the Manitoba Medical College. He organized an undergraduate teaching programme in anaesthesia in which each student commenced by anaesthetizing animals during his course in physiology, spent two and a half weeks in anaesthesia in the operating room in his fourth year and two months in his fifth year. From 1907 Webster devoted his whole time to the specialty until his death in 1934. He was perhaps the first anaesthetist in Canada to undertake animal research in his subject. In 1924 Mosby published his book The Science and Art of Anaesthesia which was the first Canadian textbook in the specialty. ${ }^{20}$

Dr. Samuel Johnston became interested in anaesthesia during his internship and in 1904 was appointed to organize a Department of Anaesthesia at Toronto General Hospital. In 1907 he was appointed Lecturer in Anaesthesia at the University of Toronto and from that time devoted himself entirely to the teaching and practise of anaesthesia. Samuel Johnston's stature in the specialty was recognized by his nomination in 1926 as President of the Section of Anaesthetics of The British Medical Association. He retired from his university appointments in 1934 after a tenure of 30 years.

The contributions of Johnston and Webster to the literature of the specialty were classics in their time, but their lasting and important contribution was the status which they developed for their specialty and, particularly in the case of Samuel Johnston, his influence in recruiting a group of dedicated and out standing physicians to join him in the practise of the specialty.

The period about and just following World War I is notable for the development of hospital departments and the emergence of pioneer anaesthetists across the country, whose contributions to development of the specialty in their local areas and on the national scene were important. In Nova Scotia, Walter Muir at Halifax; Charles Laroque, S.W. Nagel, Wesley Bourne and Harold Griffith in Montreal; Harry Shields, Charles Robson, W.E. Brown, Ralph Hargrave 
and Kenneth Heard at Toronto; William Cody in Hamilton; Beverley Leach in Regina; John Blezzard in Edmonton, Alberta, and later in London, Ontario; Ernest Watt in Edmonton; J.W. Thompson, Baston and David Freeze in Vancouver.

Up to the time of World War II anaesthesia was a major interest but not a full-time pursuit for most physicians engaged in the specialty in Canada. During the years from 1939 to 1945 many young Canadian physicians were introduced to anaesthesia as a full-time occupation in the armed services and found in the specialty an absorbing and satisfying clinical experience and an outlet for scientific and research interests in a field demanding answers to innumerable questions. The growth of the specialty in Canada in the past 30 years in terms of professional and scientific scope is a direct result of the recruitment of that wartime generation of anaesthetists. The subsequent expansion of the interests of the anaesthetist into the fields of resuscitation, intensive care, management of pain and the ongoing basic and clinical research designed to enlarge our knowledge and to improve our art is a matter of recent history and present preoccupation, the detail of which is beyond the scope of this dissertation.

\section{Contributions}

Canadian anaesthetists may be proud of the contributions to the science and practice of anaesthesia made by practising anaesthetists and basic scientists. Unfortunately it is impossible in a presentation of this kind to make personal mention of all the individuals who have contributed significantly to the development of our knowledge of the art and science of anaesthesia and I propose here to speak only of a few important contributions of the past.

At McGill University Dr. Wesley Bourne, a practising anaesthetist, was, throughout his career, a member of the Academic Staff of the Department of Pharmacology. His extensive laboratory and clinical studies of the pharmacological action of anaesthetic agents and ancillary drugs on the body systems were of the greatest importance and brought him many honours. Dr. Bourne was the first recipient of the Hickman Medal in Britain and he was the only Canadian ever elected to the office of President of the American Society of Anesthesiologists.

At Toronto the Department of Anaesthesia has always been fortunate in having a close and fruitful association with the Department of Pharmacology. Professor Veliyen Henderson, who was in the Department of Pharmacology at the University of Toronto from 1904 until his death in 1945, had an intense interest in the Pharmacology of Anaesthetic agents and his work on the purification of ether, the pharmacology of ethyl chloride and his search for new agents were of particular importance. Dr. W. Easson Brown, a member of the Department of Anaesthesia and of the staff of the Toronto General Hospital was also a part-time member of the Department of Pharmacology. In March 1923 Dr. Brown described the anaesthetic properties of ethylene, based on his laboratory and clinical experiments. ${ }^{21}$ At the time he was quite unaware of the work being done at the same time by Luckhardt, whose paper appeared a short time after Brown's publication. 22 In 1929 Professor George Lucas and Professor Henderson discovered and described the anaesthetic properties of cyclopropane. ${ }^{23}$ The first human subjects anaesthetized with cyclopropane were Professor Henderson, Professor Lucas, and Dr. Frederick Banting, famous as the discoverer of insulin. ${ }^{24}$ The more recent contributions resulting from this collaboration between anaesthesia and pharmacology at Toronto include the elucidation by Werner Kalow of the pharmacogenetics of plasma cholinesterase and its relationship to the use of relaxants in anaesthesia and the pioneering work of Kalow and Britt in the field of malignant hyperthermia.

The introduction of curare to clinical anaesthesia in 1942 by Dr. Harold Griffith ${ }^{(2.5)}$ of Montreal initiated a train of events which has changed the face of anaesthesia and the shape of clinical surgery.

\section{Organization and Canadian Anaesthesia}

While a medical specialty is recognized when a body of knowledge and/or pattern of practise unique to the discipline is seen to exist, a specialty perhaps does not come of age until numbers and community of interest stimulate association in a specialist society. This happened in Canada in the year 1920 and the moving spirits in the formation of the Canadian Society of Anaesthetists were Dr. Wesley Bourne and Dr. Samuel Johnston. The first Annual Meeting of the Canadian Society was held jointly with an organization known as "The Interstate Association of Anaesthetists" and with The New York Society of Anaesthetists in Niagara Falls in the first days of June, 1921. I have been privileged to obtain a copy of the programme of that first meeting from the Guedel Library Museum in San Francisco, through the kindness and good offices of Dr. Rod 
Calverley. I think you may be interested to see some of the pages of this programme (Figures 4 , $5 \mathrm{a}, \mathrm{b})$. The titles might well be from a programme in 1977. Attached to this programme is a page of advice which strikes me as having contemporary relevance, and $I$ recommend it to you (Figure 6 ).

The joint meeting of the Canadian Society with two American Societies indicates the long association of andesthetists of our two countries. There is an interesting item in the list of nominations for officers of the Canadian Society of Anaesthetists for the subsequent year (Figure 7). It has pleased me greatly to see that The Canadian Society had an officer known as The Executive Officer for the United States. I need hardly observe that Dr. Frank McMechan, the nominee for this office, is a familiar name in the annals of anaesthesia organizations of this continent.

The Canadian Society of Anaesthetists formed in 1920 held annual meetings for seven years. One

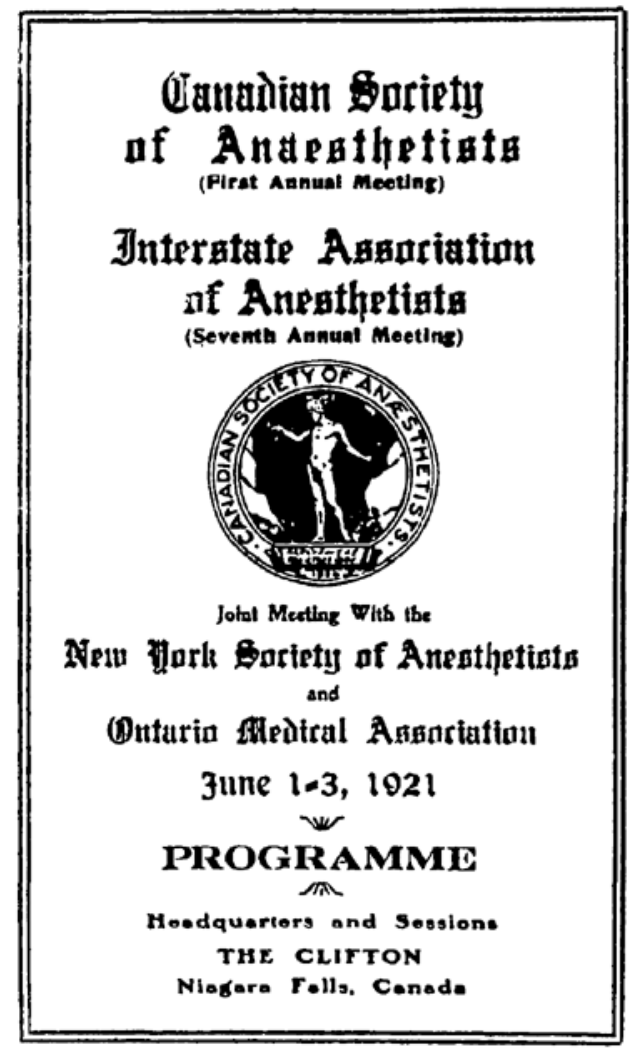

Figure 4 Cover of the programme for the Firs Annual Meeting of the Canadian Society of Anaesthetists, June 1921 . of my elders once told me that it went out of existence because the Society elected a Secretary who did not write letters. In fact the Society disbanded to become the Anaesthetic Section of the Canadian Medical Association. By 1943, however, it had become evident that Canadian anaesthesia needed a recognizable separate voice and, under the stimulus of the senior anaesthetists of Montreal and Toronto, the separate Society was reconstituted and incorporated as the Canadian Anaesthetists' Society. Since that time the Society has effectively represented Canadian anaesthesia and Canadian anaesthetists in the development and upgrading of standards of training and qualification in the specialty, in stimulating the development of academic departments of anaesthesia in the medical schools, improvement of the economic situation of the practising anaesthetist, stimulation of research in anaesthesia and allied medical sciences and continuing education in the specialty through scientific meetings and the publication of a journal.

For many years Canadian anaesthetists were active members of the American Society of Anesthe siologists and Canadians were represented by one member of the Board of Directors of your Society. As the Constitution of the American Society evolved, "component societies" became an important part of the political and administrative structure. It was apparent that since our political and economic problems, our training programmes and specialist qualifications in Canada differed from those in the United States it was nol appropriate for the Canadian Anaesthetists' Society to be a component of the American Society of Anesthesiologists. Our relationship is now one of friendly collaboration.

Canadian anaesthetists have played a prominent role in international organizations of anaesthesia. Since its foundation under the aegis of Dr. Frank McMechan, Canadians have been prominent in the governance of the International Anaesthesia Research Society. Dr. Kenneth Heard of Toronto and Dr. Harold Griffith of Montreal were Chairmen of the Board of Governors of that Society.

The formation of the World Federation of Societies of Anaesthesiologists was in large part a response to the initiative of Dr. Harold Griffith of Montreal. Dr. Griffith became the first President of the Federation in 1955, and the Canadian Anaesthetists' Society is one of the Founding Member Societies. 


\section{progranume}

Tulconesony Gaternoon, Fune ।

\section{THE CLIFTON}

\section{Scienttile פcosion. 2 ;. m.}

Symposinu of Anosthesia and the Circulatury System.

Clinical Olsservatims of the Fiffects of Dporitions and Alisalisenia in Blood l'ressiste.

$$
\text { C. 2. Weilis, A:. D., Syracusc, N. Y. }
$$

Clinical Studicy in Circulatory Depression from Ancsliresia IRecords.

E. 1. Ackesson, M. D., Toledn, Ohio.

Cireulatory and Olter Rencxes under Various Ether Tensions. E. A. Tyler, M. D., Rhiladiclilia, Pה.

Blood Pressure Reastions under Elber-Oil Coivnic Anasslliesia G. Mi. Gedert, M. D., Ollawa, Canatla.

Clinicat Studics on the Riffects of Vhrieus Nitrous Oxid. Oxvect Administration on Blood Pressure and Some Consider. ations of Rebreathing in P'olonged Atcesthesia.

Geo. W. Tong, M. D., Brooklyn. N. Y.

The Cardiac Reserve in Fibruid Operations.

T. D. Buchana, M. D., New York City.

\section{Ueneral Discussion}

Executive Session
Drogtammile

Tburgany Zlftermoon, ₹une 2

THE CLIFTON

Sclentifte $\$$ cogion, 2 p. m.

lhe Valus of Experl Aucstlesia to All Concentect.

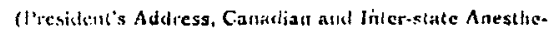
tists).

Sanue! Jolunston, M. D., Toronto, Canada.

The Patholigy aud Treatnent of Chronic Brain Injuries with a View to Determining the Safust Operative leriod.

Win. Share, M. D., Neiv York City.

Anasthesia for Brain Tunor Operations.

C. T. W. Hirsch, M. D., London, Eng.

Synergistic Anestlesia and Analyesia with Nitrous OxidOxj'grel aud Maglucsium Sul|phate.

J. T. Gwathmey, M. D., New York City.

l'usloperative Complicalious of the Respintory Tract.

iI. Ryersun Decker, N. D., Pittsburgli, Pa.

Morbidlity and Mtortaiily in Obstetrics as Infinenced by Anacthesia.

Wesley Sourue, M. D., and Jas. W. Duncan. M. D., Montreal, Canada.

FIGURE S(a and b) Pages from the First Annual Meeting of the Canadian Society of Anaesthetists held jointly with the Interstate Association of Anesthetists and the New York Sociely of Alresthetists, June 1921.

\section{Practice of Anaesthesia in Canada}

The present status of the practise of anaesthesia in Canada is to a large extent due to the fact that, like other clinical specialists, Canadian anaesthetists are remunerated on a fee-forservice basis. This has not been universally true in the past.

It was long apparent that the specialty of anaesthesia could develop and mature only in an environment in which anaesthetists were independent practitioners of medicine like other clinical specialists, and not hospital employees. The achievement of that goal was hard-won and largely due to the influence of the Canadian Anaesthetists' Society.

The Profession of Medicine in Canada has for some years been the beneficiary or the victim of the Welfare State - depending on the individual point of view. Universal health insurance is a fact of life. The rules vary from one provincial jurisdiction to another and some of these rules have caused difficulties for anaesthetists. On the whole, however, the specialty has found it possible to live with this new social situation, although resenting the accompanying instrusion of government and bureaucracy into the practice of medicine.

\section{Academic Anaesthesia in Canada}

I have previously referred to the appointment of Lecturers in Anaesthesia at the University of Toronto and the University of Manitoba in 1907. At Manitoba, anaesthesia was in the Department of Surgery and, at Toronto, in the Department of Medicine. The first independent Department of Anaesthesia was formed at McGill University under the chairmanship of Dr. Wesley Bourne in 1945. There are now independent Departments of Anaesthesia in each of the Canadian Medical Schools. Unfortunately the financial support available to these academic departments is in 


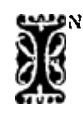

OUR MODERN, ENTHUUSIASM FOR ORGANIZA. TION, WE ARE IN DANGER OF FORGETTING TIAT SYSTEM AND SURVEY AND ENCYCLO. PEDIC KNOWLEDGE CAN NEVER SUPPLANT REAL THINKING. THINKING IS, AFTER ALL, AN IN. DIVIDUAL PERTORMANCE. COMPANIES OR GROUTS GF PERSONS DO NOT THINK TOCETHER OR DEVISE OR INVENT ANYTHING OR ANY PROCESS EXCEPT IN SO FAR AS THEY PUT TOGETHER, ORGANIZE AND COMPARE TIE PRODUCTS OF INDIVIDUAL MINDS. WE MUST NOT BECOME BLIND TO THE LIMITATIONS OF ORGANIZING INVESTIGATIVE EFFORT. A PLEA FOR THE INDIVIDUAL KORKER IN SCIENCE IS TIMELY. HE MUST BE ENCOURACED AND PERMITTID TO UNFOLD IIIS OWN PERSONALITY AND POINT OF VIEW WITH AN OPEN MIND RATHER THAN TO BE BIASED BY THE PROJECTS OF A COMPANY OF SCHOLARS. LET US BY ALL MEANS FACILITATE THE PROGRESS OF SCIENCE BY FUR. NISHING THE REQUISITES FOR RESEARCH; BY ORCANIZED EFFCRTS TO PROMOTE THE AINS AND SET FORTH TIHE RESULTS; BY SYSTENATIC PLANNING AND CO-ORERATION IVHICH WILL MAKE RSTABLISIIED FACTS EASILY AVAILABLE AND WIDE! KNOWN. BUT ANID THIS GROWTH OF TIE GET.TOGETHER SPIRIT AND BETTER INTELLECTUAL COMMUNITY LET US ALWAYS BEAR IN MIND THE INDIVIDUAL WHO DOES THE THINKING. GENIUS IS FOUND IN MEN, NOT IN ORCANIZATIONS.

Figure 6 Page from the programme of the First Annual Meeting, Canadian Society of Anaesthetists, June 1921 .

most instances seriously inadequate and all continue to suffer shortages of manpower. Research in anaesthesia also suffers from lack of continuous funding and a shortage of trained investigators. These are the problems for the future.

\section{Professional Standards and Qualification}

Finally, an important part of the history of anaesthesia in Canada is the development of standards of professional qualification and training in the specialty.

It appears that the first Canadian interneships or residencies for special training in anaesthesia were established in Toronto in 1934, with one "Senior Interne" in each of the Toronto General Hospital, St. Michael's Hospital and the Hospital for Sick Children. In 1936 there was one similar appointment at the Royal Victoria Hospital in Montreal. These provided one year of training. During the years from 1939 to 1945 there was a demand for special training for anaesthetists for the armed forces and short courses were developed in Montreal, Quebec City and Toronto. After 1945 these courses developed into formal training programmes to meet the requirements for Specialist Certification established by the
Royal College of Physicians and Surgeons of Canada and, under this same stimulus, similar programmes of three to four years' duration were shortly available in each of the Canadian medical centres.

Until 1939 any practitioner with a general medical licence was free to label himself "Specialist". In that year the Royal College of Physicians and Surgeons of Canada was empowered by legislation to certificate Specialists in Medicine and Surgery, although the first certificates were not issued until 1942. Subsequently the licensing authorities in most of the Canadian provinces made such certification mandatory for the designation of a Specialist. Unfortunately when the list of authorized specialties was first issued anaesthesia was not included and there was strong opposition to its recognition as a specialty from some senior physicians. As a result of vigorous representations by the Canadian Anatsthetists' Society, anaesthesia was added to the

\section{Canndan geclety of Anaestbetigto}

\section{nominations for $1921=22$}

Willian Wetseter, M. D., Winnipeg, President.

Davis H. Amolt, M. D., Icondon, Vice-Pretident.

F. H. MlcMechan, A. M., M. D., Executive Officer for the United States.

Wesley Bourne, M. D., Montreal, Secrctary-Treasurer.

Executive Coinnittee :

J. L. Allen, M. D., Calgary.

W. G. Hepburn, M. D., Alontreal.

Ttromas R. Hauley, B, A., M. B., Torouto.

Cliarter LaRocque, B. A., M. D., Monireal.

Walter L. Muir, M1. D., Halifax.

\section{Interstate Agsociation of Finestbctista} Mominations tor 1921.22

Arthur E. Guedel, M. D., Alinneapolis, Chairman. Wm. T. Shannon, D. D. S., Detroil, Vice-Chairntan. F. H. McMechan, M. D., Avon Lake, $O$., Scc.-Treasurer. Lamora Shuey, M. D., Toledo, O.

5. Grifith Davis, M. D., Baltimore.

J. Wade Elphinstone, M. D., Pittsburylu.

O. C. Hickman, D. D. S., Denver.

Robert E. Jameson, M. D., Davenport, la.

Charles N, Coombs, M. D., Terrc Hzute, Ind.

(Members are roquosted to submlt further nominatlons in writing or trom the Floor at the timo of elcetlon.)

Figure 7 Nominations for officers of the Canadian Society of Anaesthetists and the Interstate Association of Anesthetists for 1921-22. From the programme of the First Annual Meeting, Canadian Society of Anaesthetists, June 1921. 
list of specialties in the Medical Division of the College before the certification programme was implemented. Both the College and the anaesthetist s have insisted that the duration and quality of training in andesthesia should be identical with that in all other recognized specialties and that the qualifying examinations should be in all ways comparable. The quality of training programmes is monitored by the Royal College and since 1974 all recognized postgraduate medical education has been the responsibility of the Faculties of Medicine of the universities. This has assured the status of anaesthesia amongst the specialties of medicine.

It must be accepted that not all communities in Canada can be served by specialist anaesthetists. Smaller towns and rural communities will continue to rely upon the general practitioner. These practitioners require training. It is fast becoming mandatory that practitioners who provide anaesthesia in small community hospitals will have a minimum of special training in anaesthesia. The Council on Hospital Accreditation now calls for six months of training in an approved centre for such practitioners. In two of our provincial jurisdictions this has been extended by regulation to a minimum of one year and in one province to two years. This should greatly improve patient care in these smaller communities.

\section{Conclusion}

I have endeavoured in this brief summary to outline for you the development of the specialty of anaesthesia in Canada. Time has not permitted me to mention the contributions of a host of individual physicians who have made this whole development possible and I must beg forgiveness for the omissions.

\section{REFERENCES}

I. Editorial Note. Employment of sulphuric ether vapour in Montreal, Quebec, and Sherbrooke. Brit. Am. J. Med. Phys. Sc. 2: 338 (1847).

2. NeLSON, H. Experiments with the sulphuric ether vapour. Brit. Am. J. Med. Phys. Sc. 3: 34 (1847)

3. Worthington, E.D. Case of amputation of leg. the patient under the influence of sulphuric ether vapour. Brit. Am. J. Med. Phys. Sc. 3: 10 (1847)

4. Parker, W.F. "Daniel McNeill Parker, M.D. His ancestry and a memoir of his life". Toronto, William Briggs (1910).

5. STEWARD, D.J. The early history of anaesthesia in Canada: The introduction of ether to Upper Canada, 1847. Can. Anaes. Soc. J. 24: 153 (1977).

6. SIMPSON, J.Y. Discovery of a new anaesthetic agent, more efficient than sulphuric ether, Lond Med. Gaz., N.S., 5: 934-7 (1847).

7. Worthington, E.D. Cases of chloroform. Brit. Am. J. Med. Phys. Sc. 3: 326 (1848).

8. Holmes, A.F. Employment of chloroform. Brit Am. J. Med. Phys. Sc. 3: 263-264 (1848).

9. JaCQues, A. 325th anniversary: anesthesia, past and present. Anesth. \& Analg. 45: 15-20 (1966).

10. JOHNSTON, $S$. The growth of the specialty of anaesthe sia in Canada. Can. M.A.J. 17:163 (1927).

11. Graham, J. First death from chloroform at Toronto General Hospital. Can. J. Med. Surg. 29 206-212 (1911)

12. RoLAND, C.G. The first death from chloroform at the Toronto General Hospital. Can. Anaes. Soc. J 1: 437-439(1964)

13. EdITORIAL. Can. Lancet. 1: 5 (1863)

14. Clarke, C.K. The history of the Toronto General Hospital. Toronto, William Briggs (1913).

15. CULLEN, T.S. The house surgeons of the Toronto General Hospital, 1890-1891. Can. J. Med. Surg. $52: 66(1922)$

16. RoLAND, C.G. Bibliography of the history of anaesthesia in Canada: preliminary checklist. Can. Anaes. Soc. J. 15: 202-214(1968).

17. O'REILLY, C. An anaesthetic chart. Can. Lancer 34: 636-637 (1901).

18. Cushing, $H$. On routine determinations of arterial tension in operating room and clinic. Boston Med. Surg. J. 148: 250-256 (1903)

19. Webster, $W$. Notes on the development of anaesthesia in Western Canada. Can. Med. A. J. 17 727-728 (1927).

20. WEBSTER, W. "The science and art of anaesthesia". C.V. Mosby Co., St Louis (1924).

21. Brown, W.E. Preliminary report: experiments with ethylene as a general anaesthetic. Can. Med. A. J. 13:210 (1923).

22. LuCKhardT, A.B. \& Carter, J.B. Ethylene as a gas anaesthetic: preliminary communication. $\mathrm{J}$ Am. M. A. 80 : 1440 (1923).

23. LuCas, G.H.W. \& Henderson, V.E. A new anaesthetic gas: cyclopropane. Can. M. A. J. 21: $173-175(1929)$.

24. LuCAs, G.H.W. Letter to the editor. Can. Anaes Soc. J. 15: 215 (1968).

25. Griffith, H.R. \& Johnson, G.E. The use of curare in general anaesthesia. Anesthesiology 3:481 (1942). 